\title{
Deposition Hydroxyapatite /Titania Composite on Ti-6Al-7Nb Alloy for Human Body Implants
}

\author{
Dunya Abdulsahib Hamdi ${ }^{1,2}$ \\ ${ }^{1}$ Department of Prosthetics \&Othotics Engineering, Al -Nahrain University, Baghdad, IRAQ. \\ ${ }^{2}$ Surface Analysis and Materials Engineering Research Group, School of Engineering and Information \\ Technology, Murdoch University, Murdoch, WA 6150, AUSTRALIA
} dunia_sh_7@yahoo.com

Received: 28-Jan.2018 Revised: 29-March-2018

Accepted: 18-Sep.-2018

\author{
http://doi.org/10.29194/NJES.21040467
}

\begin{abstract}
The microstructural analysis and electrochemical measurements tests were used to investigate the behaviors of $\left(\mathrm{TiO}_{2}\right)$ and $(\mathrm{HAp})$ coated Ti-6Al-7Nb alloy in the SBF solution .By using $\mathrm{RF}$ sputtering, a thin $\mathrm{TiO}_{2}$ layer coated the substrate, while a thick layer of HAp coated the outer side of surface. The generated middle layer consist of the composite of $\mathrm{TiO}_{2}$ and $\mathrm{HAp}$ which is by AFM characterized as uniformly distributed coating system with nano size. The images of the scan electron microscopy (SEM) shows that there is no any cracking observed in the outer layer of tested samples due to the use of thin film $\mathrm{TiO}_{2}$ as mid lead to reduce the difference in the thermal expansion between the HAp material and Ti-6Al$7 \mathrm{Nb}$ substrate .The HAp upper layer significantly improve the bioactivity of the Ti-6Al-7Nb alloy. In this study, the bonding strength and the corrosion resistance was improved by using thin layer of $\mathrm{TiO}_{2}$. From electrochemical impedance spectroscopy (EIS) study Bod plot, the composite layer of $\mathrm{TiO}_{2}$ and $\mathrm{HAp}$ was suggested by the capacitive act as barrier layer coated substrate and prevent the relays of the ion from metallic. The results shows the values of $R_{\mathrm{ox}}\left(309.2 \mathrm{k} \Omega \mathrm{cm}^{2}\right)$ are greater than for $\mathrm{R}_{\mathrm{ct}}\left(19.2 \mathrm{k} \Omega \mathrm{cm}^{2}\right)$, by assumes the presence oxide film increases for coated substrate are greater than that of uncoated, which is a result of the presence of coated film that improve the corrosion resistance of the sample.
\end{abstract}

Keywords: Magnetron sputtering, Hydroxyapatite, Ti-6Al-7Nb alloy, Titania, Electrochemical Corrosion

\section{1- Introduction}

The metallic materials titanium (Ti) alloys are widely used in manufacturing of implants material because their high toughness and strong strength [1]. The ability of Ti alloy to interact with body fluids might cause adverse effects to the surrounding tissues due to release of ions from metallic [2]. The hydroxyapatite (Ca10(PO4)6(OH)2, HAp) used to modificate the metallic implant to improve the activity of the surface [3]. The difference in thermal expansion coefficients between HAp $\left(13.6 \times 10^{-6} / \mathrm{K}\right)$ and $\mathrm{Ti}$ alloy $\left(8.6 \times 10^{-6} / \mathrm{K}\right)$ lead to mismatch between coated and substrate, so other material like $\mathrm{TiO}_{2}$ is used as thin mid layer between the substrate and HAp which have thermal expansion (7.249 $\times$ $10-6 / \mathrm{K})$ approximately near the thermal expansion of substrate $[4,5]$. From literatures review, there were many attempts have been made to form a thick $\mathrm{TiO}_{2}$ layer on the Ti substrate because they found that the corrosion resistance of implants material is increases with increasing the thickness of the oxide layer on the surface. The improved biocompatibility and biological processes of implants using HAp coatings is belong to the biological and chemical similarity of HAp to biological types tissues, and it's could direct bonding to the bones [6]. Different methods are used for coating such as chemical and physical vapor deposition, such as electrophoretic, laser beam, ion implant and solgel method [7-9]. Plasma sputtering is currently the one of the beast method commercial process was used for deposited ceramic such as HAp and $\mathrm{TiO}_{2}$ coatings on metallic implants. This belong to the film coated with good adhesion, high quality, full cover with low porous [8]. The Ti$6 \mathrm{Al}-7 \mathrm{Nb}$ alloy was achieve due to, (i) a dense and stable passive surface layer, (ii) high corrosion resistance (iii) good mechanical properties [4]. The aim of the present work is to enhance the properties of the bioactive of the Ti6-Al-7Nb alloy. The $\mathrm{TiO}_{2}$ film coated the alloy as mid layer to enhance the adhesion between the HAp layer and Ti6-Al-7Nb substrate and hence increasing the corrosion resistance of the substrate. The HAp was used to improve the biocompatibility of surface. The materials used in this work are powder targets (4 5um $\mathrm{TiO}_{2}$ and $2 \mathrm{um} \mathrm{HAp}$ particles) with purity is $(98.999 \%)$ and $(95.999 \%)$ respectively provided from VTFM (Vacuum Thin Film Materials). The substrate used was titanium alloys (Ti-6Al-7Nb) (Baoji Jinsheng Metal Material Co. Ltd).

\section{2- Experimental procedure}

The substrate Ti-6Al-7Nb alloy was grinded, polished and cleaned ultrasonically in ethanol and 
deionized water for $20 \mathrm{~min}$ at $25^{\circ} \mathrm{C}$ temperature. The RF magnetron sputtering device with frequency of $13.65 \mathrm{MHz}$ was situated in a vacuum chamber $1 \times 10^{-6}$ Torr, Ar gas (purity 99.9) atmosphere was used as sputtering gas with working pressure $5.5 \times 10^{-3}$ Torr and the distance between target and substrate equal to $5 \mathrm{~cm}$. Deposition time was controlled to 10 hours (2 hours for deposit $\mathrm{TiO}_{2}$ and 8 hours for deposit HAp) to obtain a uniform film thickness. The thickness of $\left(\mathrm{TiO}_{2}+\mathrm{HAp}\right)$ films equal to $2 \mathrm{um}$ determined using minutest (3000 of a model) device. The samples was annealed by using furnace at $600^{\circ} \mathrm{C}$ for 1 hours in still air. The atomic force microscope (AFM) were used to investigate the particle size and topography surface of (HAp and $\mathrm{TiO}_{2}$ ) layer coated with Ti$6 \mathrm{Al}-7 \mathrm{Nb}$ alloys. The scanning-electron microscopy (SEM) used to investigate the properties of surface after and before corrosion test. The driving force for formation of oxide layer on the mate under open circuit conditions. The results from EIS bode plot behavior under conditions of open circuit in simulated body fluids (SBF) solution seem to give more information for the extent reactivity surface of alloy "Ti-6Al-7Nb". The low capability of frequency $(100 \mathrm{mHz})$ made the EIS probe the relaxation phenomena readily detected including surface intermediates and thus studying the mechanisms of passivation and electrochemical corrosion [10]. The used SBF containing concentrations of ion which is similar to those in human body. The solution of simulated body fluids (SBF) which is suggested by Kokubo [11] $0.305 \mathrm{~g} \mathrm{MgCl} 26 \mathrm{H} 2 \mathrm{O}, 0.2775 \mathrm{~g} \mathrm{CaCl} 2,0.071 \mathrm{~g}$ $\mathrm{Na} 2 \mathrm{SO} 4,7.9949 \mathrm{~g} \mathrm{NaCl}, 0.3528 \mathrm{~g} \mathrm{NaHCO} 3$, $0.2235 \mathrm{~g} \mathrm{KCl}, 0.147 \mathrm{~g} \mathrm{~K} 2 \mathrm{HPO} 4$, in $1000 \mathrm{ml}$ distilled water and $\mathrm{pH}$ adjusted to 7.4 at temperature of $37 \mathrm{C}^{\circ}$, the samples were soaked in $\mathrm{SBF}$ at test of electrochemical measurements.

\section{3- Results and Discussions}

A- Atomic Force Microscopy (AFM )

Figure (1.a) shows AFM as evidence by the scanning process for an area with dimensions pixels(48*49) for films HAp prepared by RF sputtering coated $\mathrm{Ti}-6 \mathrm{Al}-7 \mathrm{Nb}$ alloy and annealing at $600^{\circ} \mathrm{C}$. Have semispherical peaks which is useful for medical application. The image shows the particle with micro size although the scale of particle with nano size, these belong to aggregation of particles. Fig.(1.b) have range of particles with nano size $(50,00 \mathrm{~nm}-120,00 \mathrm{~nm})$ and the largest number of particle size HAp through $90,00 \mathrm{~nm}$. That is mean the coating RF sputtering process work to convert the particle size of target from micro to nan size

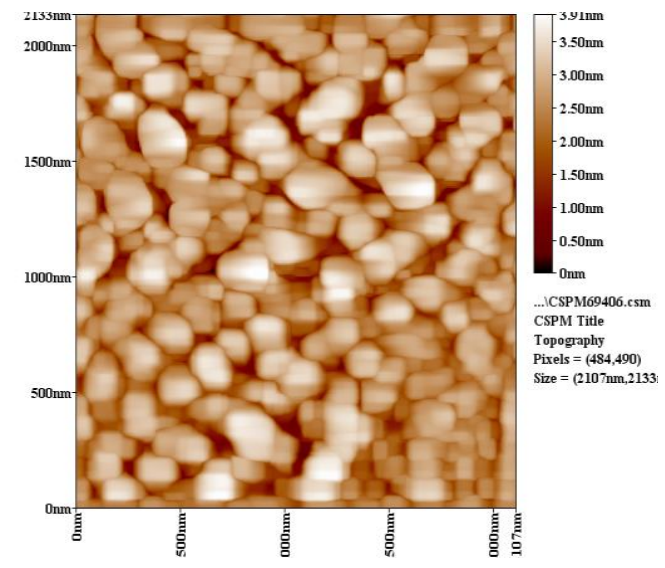

(a) AFM scan pros

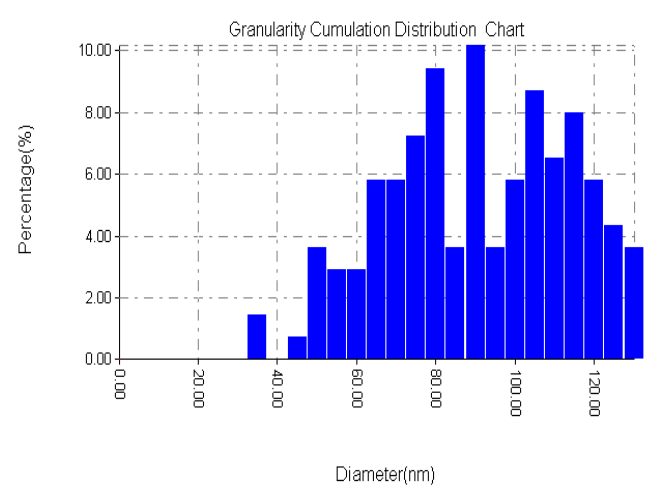

(b) The range of particle size and distribution Figure 1: Top view scan process and range of particle size for ceramic HAp in nano size coated Ti-6Al-7Nb alloy.

B- Scanning Electron Microscope (SEM) before corrosion.

The morphologies surface of coated specimens are shown in Figure (2). In general, the observation of the image of SEM shows that the coated layer is smooth and fully coated substrate. Also, there are some few gaps and pores due to the heat treatment, these pores are important to connect the tissue and the used material through the implant process in the human body. It is worthy to noting that these pores work as a channels to increase the bond between the tissue and implant part. There is no any cracking observed in the outer layer of coating film belong to use thin film $\mathrm{TiO}_{2}$. 

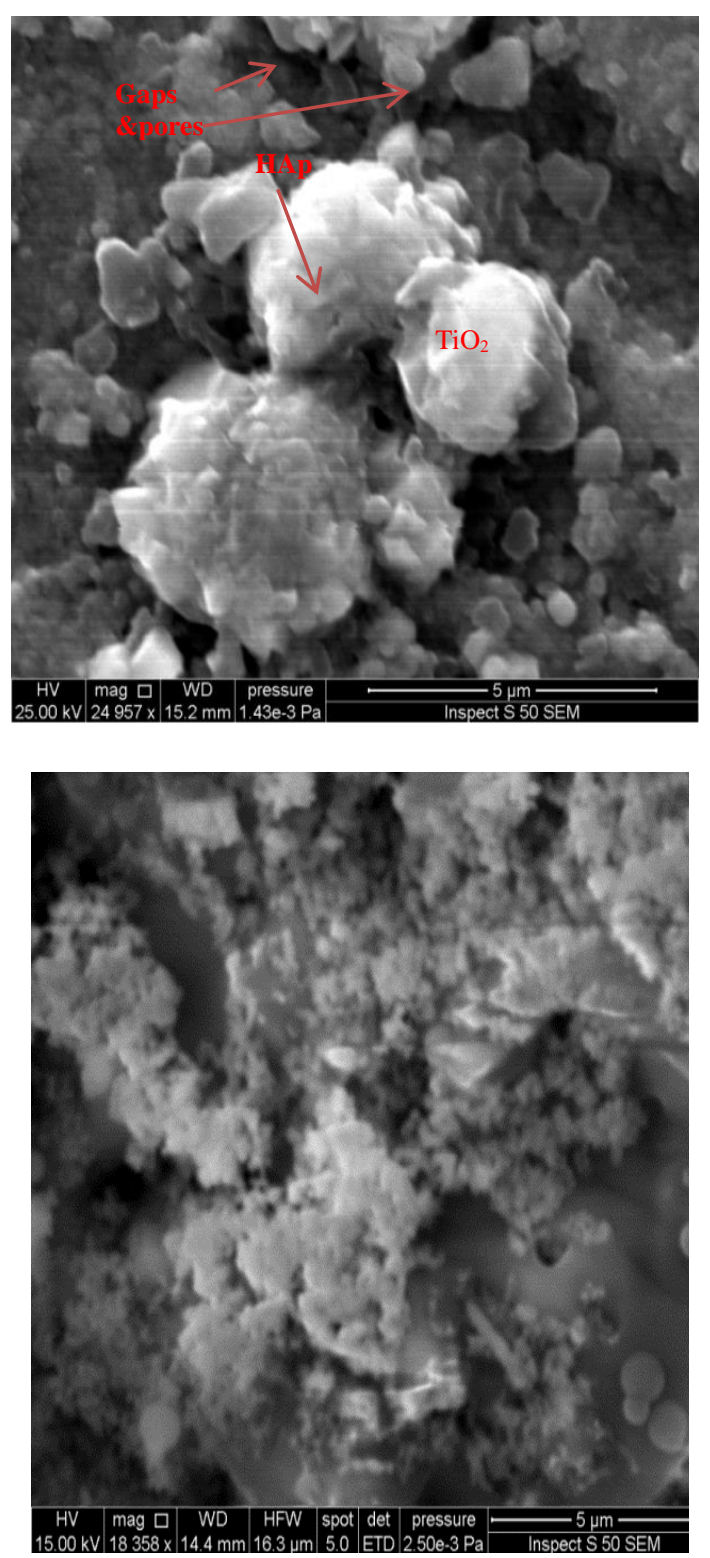

Figure 2: Morphology of $\mathrm{TiO}_{2}$ and HAp coating Ti-6Al-7Nb alloy.

Figure (2.a-b) shows the needle shape belong to growth $\mathrm{TiO}_{2}$, the circular and lumbar were belong to growth Hap. The grain growth is associated with volume expansion due to heat treatment and it having the thermal expansion mid value between $\mathrm{Ti}$ alloy and HAp lead to reduce the difference in the thermal expansion between the HAp material and substrate during heating and cooling. Oxidation reaction which is similar to result obtained from composite $\mathrm{TiO}_{2}$ and HAp coated $\mathrm{Ti}$ alloy using electrophoretic deposition [5]. Figure (2.b) clearly shows the aggregation for HAp nano size particles on the surface of sample with big flowers, this belongs to the (HAp and $\mathrm{TiO}_{2}$ ) with nano size particles having strong surface charge which lead to aggregation.

\section{Electrochemical Corrosion \\ A. Scanning Electron Microscope (SEM) after corrosion.}
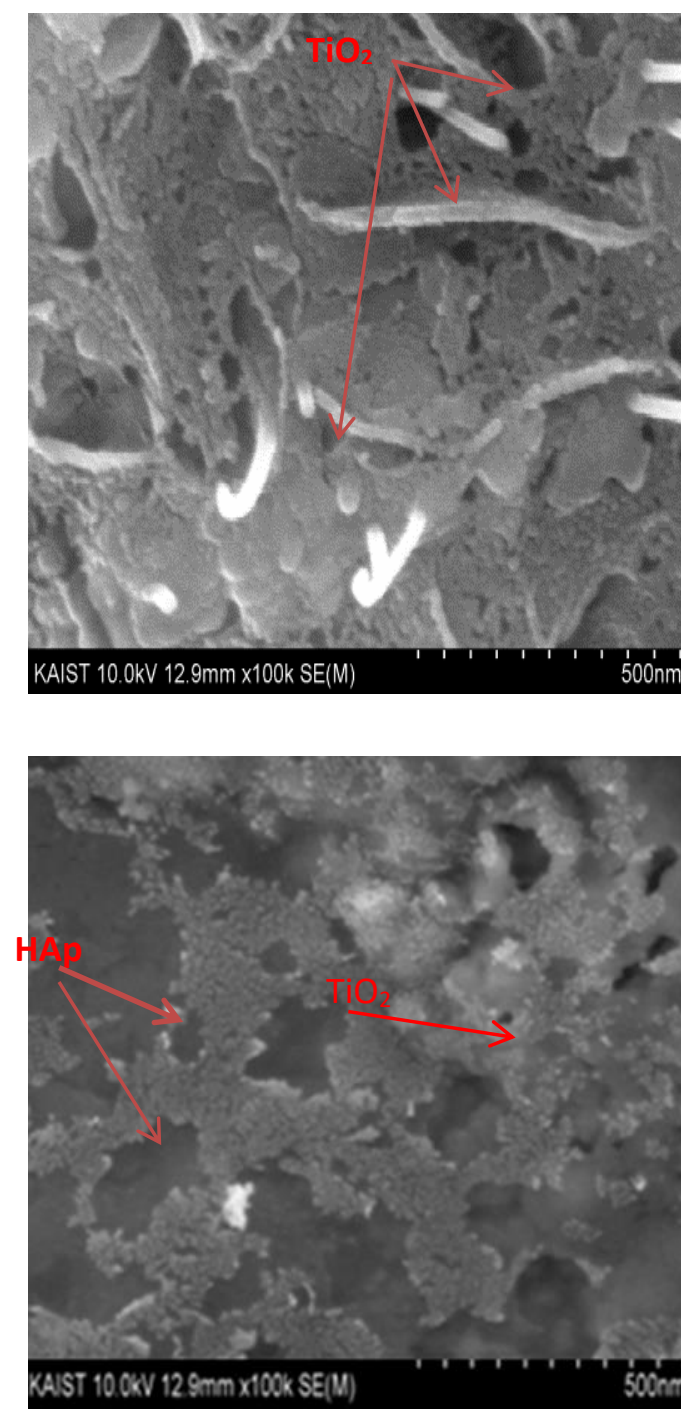

Figure 3: Morphology of $\mathrm{TiO}_{2}$ and HAp coating $\mathrm{Ti}-6 \mathrm{Al}-7 \mathrm{Nb}$ alloy after corrosion.

Figure (3.a-b) shown the effect of corrosion test on surface samples. The surface become more smooth due to chemical interaction between surface and ions composite of SBF with reaming small size of HAp. Thin layer $\mathrm{TiO}_{2}$ coatings growth through gaps and porous with needle shape. The needle crystals shape of the $\mathrm{TiO}_{2}$ coating provides the bio logically compatible coating for medical application [12].

B. Electro chemical corrosion bode plots

Figure (4.a-b) showing two segments lines, these lines corroborating to form passive layer represent corrosion bode plots of uncoated and coated $\mathrm{Ti}-6 \mathrm{Al}-7 \mathrm{Nb}$ substrate with $\left(\mathrm{HAp} \& \mathrm{TiO}_{2}\right)$. The first line $(\log (\mid \mathrm{Zl})$ vs. $\log ($ freq $))$ is representing the formation of a thin barrier of layer of oxide, while the second line ( phase $(\mathrm{Z})$ vs. $\log ($ freq $)$ ) is related to thick outer film layer 
formation. The thickening rates form of the outer $\left(\mathrm{HAp} \& \mathrm{TiO}_{2}\right)$ and inner oxide form.

This behaviour suggests that medium of SBF is favours self-passivation of Ti-6Al-7Nb (coated and uncoated) alloys, While the highest efficacy a chive in the direction of passive film formation was notice. The results shows that the addition of $\mathrm{TiO}_{2}$ and $\mathrm{HAp}$ as layers to $\mathrm{Ti}-6 \mathrm{Al}-7 \mathrm{Nb}$ mechanical traits improves by increasing the ability of the passive layers on the chemical dissolution to material of surface in (SBF) medium which is similar to result obtained from Wua. C and Ramaswamy [3]. The passive layer enhancement by addition of $\left(\mathrm{TiO}_{2}\right.$ and $\left.\mathrm{HAp}\right)$ as layers to $\mathrm{Ti}-6 \mathrm{Al}-7 \mathrm{Nb}$ by increasing the resistance of passive layer for chemical reaction in SBF. It can be notes from inner and outer values of the substrate in comparison to uncoated alloy at SBF.(For uncoated, the solution goes inside lattice of passive film rend it high defective, and hence the film becomes low stable. Impedance scan to EIS- bode plot prior the spa cement left immerse in solution until a steady state was achieve open circuit. At frequency domain 100 $\mathrm{kHz}-100 \mathrm{mHz}$, the measurement was carried out and the results are shown as bode plots of electrodes as represented in Fig.(4a-b).The electrochemical impedance spectroscopy result are shows equally and phase angle is a sensitive index to phenomena of surface occurred at electrolyte /electrode interface $[3,13]$. As it is represent, the spectra in Fig(4b) shows high capacitive worthy belong to typical of passive materials, as represented with angle phase a remain for wide range close to $90^{\circ}$ from medium to low frequencies.

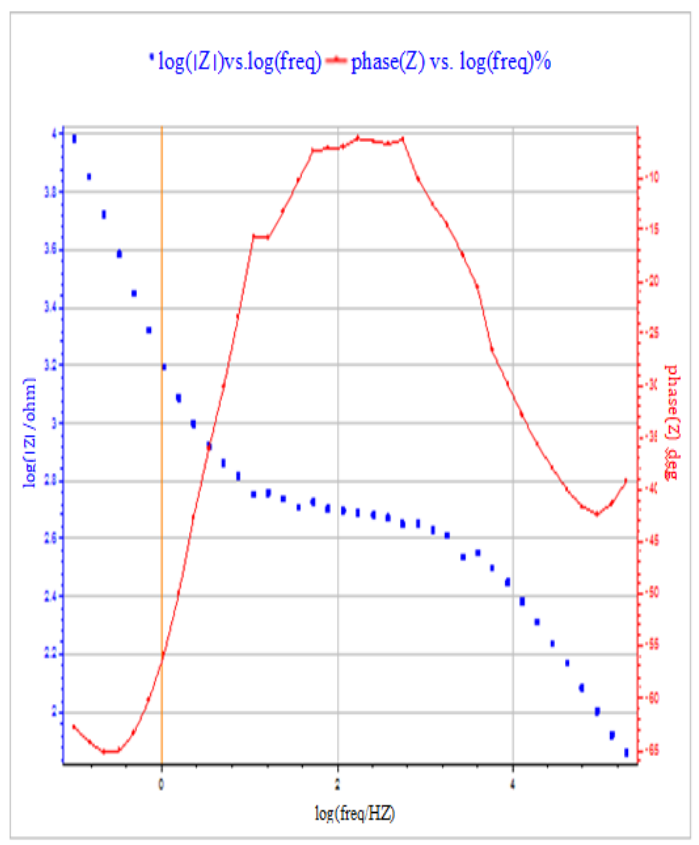

(a)

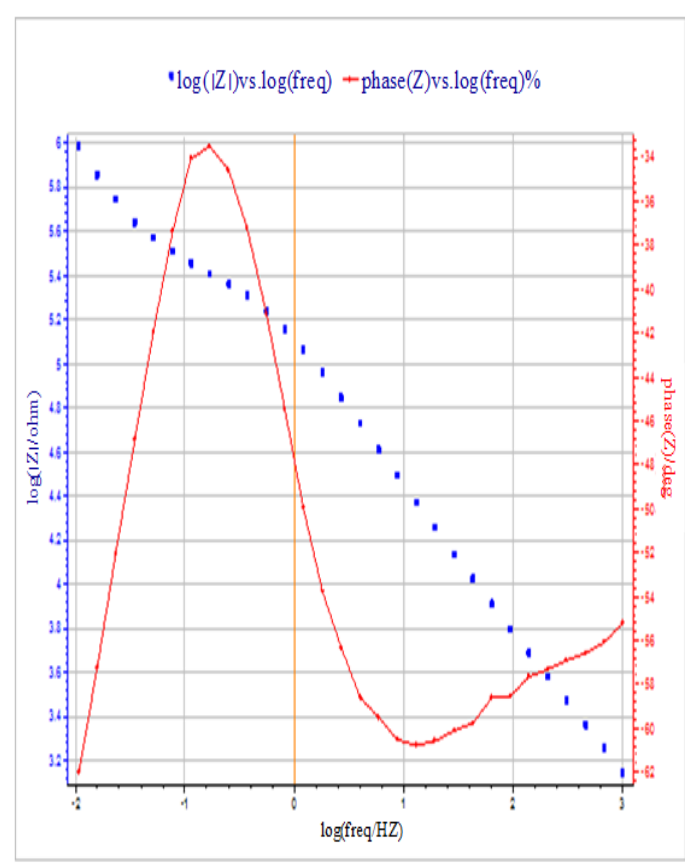

(b)

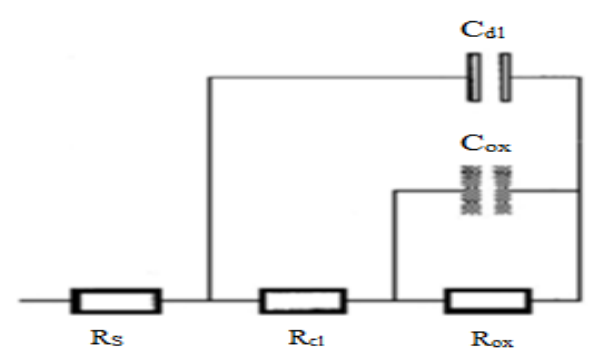

( c)

Figure 4: represent corrosion bode plots of (a) uncoated Ti-6Al-7Nb substrate (b) coated Ti-6Al$7 \mathrm{Nb}$ substrate with $\left(\mathrm{HAp}+\mathrm{TiO}_{2}\right)$ and (c) equivalent circuit of the electrical using for analysis the illustrated experimental electrochemical impedance spectroscopy data.

This behaviour is more accentuated for pure Ti-6Al-7Nb alloy and more stable film suggested to form $\left(\mathrm{TiO}_{2}+\mathrm{HAp}\right)$-coated Ti-6Al-7Nb alloy. Is observed both samples that, although it was calculated the electrochemical impedance at low frequency of $100 \mathrm{mHz}$, over this range there is no horizontal impedance plateau which can discerned in aspect, $(\log |z|-\log$ freq.) high region relation become saturated with a phase angle drops to zero degree [3]. The large phase of broad peak of angle peak show is interaction of two time constant, reflect the nature of bi-layer of passive film $\left(\mathrm{TiO}_{2}+\mathrm{HAp}\right)$ coated and $\mathrm{Ti}-6 \mathrm{Al}-7 \mathrm{Nb}$ alloy. Ti-6Al-7Nb alloy comparing barrier porous outer and inner layer [14-16]. According to these facts the EIS data were examined according to the equivalent circuit (EC) which is show in Figure (4c), the simulate solution /oxide/metal interface for Ti-6Al-7Nb alloy and 
oxid layer $\mathrm{TiO}_{2}$ [15]. EC model contain from circuit of the a simple Randles represent charge resistance transfer and layer of double capacitance (Rct and Cdl) in parallel branched arrangement with capacitance, resistance of passive film of oxide (Cox and Rox), and solution resistance (Rs) connected with whole are series. The CPE belong to apportionment times of relaxation this belong to the different surface degrees in - roughness, random, influence and differences in surface layers ingredients impedance (ZCPE) represent by [17]:

$\mathrm{ZCPE}=1 / \mathrm{Qo}(\mathrm{j} \omega) \mathrm{x}$

Where Qo is amount of $\left(\Omega^{-1} \mathrm{~cm}^{-2} \mathrm{~s}^{-\mathrm{x}}\right)$ of CPE which is belong to the idealized capacitance (Cox) at $\omega=1, \omega$ is angular frequency $(\omega=2 \pi \mathrm{f}$ $\left.\operatorname{rad~s}^{-1}\right)$, and $\mathrm{j}=(-1)^{1 / 2}$. The magnitude of $\mathrm{x}$ can be between 1 and -1 for a perfect inductor 1 for a perfect capacitor Ti-6Al-7Nb alloy.

Table 1: (A) equivalent circuit parameters for formed passive film on Ti-6Al-7Nb alloy, (B)Ti$6 \mathrm{Al}-7 \mathrm{Nb}$ coated $\left(\mathrm{TiO}_{2}+\mathrm{HAp}\right)$ constant concentration.

\begin{tabular}{|c|c|c|c|c|c|c|}
\hline & $\begin{array}{c}\mathrm{R}_{\mathrm{ox}} \\
\mathrm{k} \Omega \mathrm{cm}^{2}\end{array}$ & $\begin{array}{c}\text { Cox } \\
\mu \mathrm{F} \mathrm{cm}^{-2}\end{array}$ & $\mathrm{x}$ & $\begin{array}{c}\mathrm{R}_{\mathrm{ct}} \\
\Omega \mathrm{cm}^{2}\end{array}$ & $\begin{array}{c}\mathrm{Cdl} \\
\mu \mathrm{F} \mathrm{cm}\end{array}$ & $\begin{array}{c}\mathrm{Rs} \\
\Omega\end{array}$ \\
\hline $\mathrm{A}$ & 123.3 & 4.26 & 0.87 & 7.29 & 6.56 & 11.39 \\
\hline $\mathrm{B}$ & 309.2 & 2.68 & 0.84 & 19.29 & 12.13 & 2.83 \\
\hline
\end{tabular}

Fitting procedures by using the equation 2 transfer function [18] for proposed EC model figure (4c) adequately which represent the measured data error of $4 \%$, and the calculated EC parameters are in Table 1.

$$
Z_{B C}=R_{s}+\frac{1}{j \omega c_{d l}+\frac{1}{R_{c t}+\frac{1}{\left(j \omega c_{o x}\right)^{x}+\frac{1}{R_{o x}}}}}
$$

The results shows the values of $R_{o x}$ are greater than for $\mathrm{R}_{\mathrm{ct}}$, by assumes the presence oxide film increases for coated substrate, the corrosion resistance to the sample and the EIS data commanded by passive film characteristics.

\section{4- Conclusions}

The RF magnetron sputtering was successful to convert the particle size of ceramic coated from micro to nano size through the sputtering. Use thin layer of $\mathrm{TiO}_{2}$ is to enhance the capability of bonding of HAp layer with Ti-6Al-7Nb substrate and use HAp as up layer is to improved biocompatibility of implants. The corrosion resistance of Ti-6Al-7Nb alloy was enhancement by the $\mathrm{TiO}_{2}$ coating the alloy as confirmed by potential dynamic polarization test with time OCP increasing positively, thus indicate self- passivation for both the samples, the two layer( $\left.\mathrm{TiO}_{2}+\mathrm{HAp}\right)$ thicken rate comprising the oxide formed film is maximum. The results shown the mount of $R_{o x}$ are more than those for $R_{c t}$, $309.2 \mathrm{k} \Omega \mathrm{cm}^{2}$ and19.29 $\Omega \mathrm{cm}^{2}$ for Ti6-Al-7Nb coated with $\left(\mathrm{TiO}_{2}+\mathrm{HAp}\right)$, and $123.3 \mathrm{k} \Omega \mathrm{cm}^{2}$ and $7.29 \Omega \mathrm{cm}^{2}$ for Ti6-Al-7Nb uncoated respectively which belong to oxide layer coated lead to increasing the corrosion resistance of the Ti6-Al-7Nb alloy.

\section{References}

[1] Sittig. M. T, Spencer. N.D, Wieland. M, Vallotton .P.H" Corrosion Behavior of Ti-6Al$7 \mathrm{Nb}$ Alloy in Biological Solution for Dentistry Applications ", J. Mater. Sci.: Mater. Med. Vol .10, No.2, 199.

[2] El-Taib. F, Awad .Kh.A." lectrochemical Corrosion and Passivation Behavior of Titanium and Its Ti-6Al-4V Alloy in Low and Highly Concentrated HBr Solutions, "Int. J. Electrochem. Sci., Vol.6, No.1, pp.6483 6502, 2011

[3] Wua. C, Ramaswamy. Y" Novel sphere coatings on $\mathrm{Ti}-6 \mathrm{Al}-4 \mathrm{~V}$ for orthopedic implants using sol-gel method, "Acta Biomaterialia, Vol.4, No.11, pp. 569-576, 2008.

[4] Bolat .G, Mareci. D, Iacoban .S, "The Estimation of Corrosion Behavior of NiTi and NiTiNb Alloys Using Dynamic Electrochemical Impedance Spectroscopy" Hindawi Publishing Corporation.J. Spectroscopy, Vol.1, No.12, pp.1-7, 2013.

[5] Mohan .L, Durgalakshmi .D, Geetha .M, Sankara Narayanan .T.S"Electrophoretic deposition of nanocomposite $\left(\mathrm{HAp}+\mathrm{TiO}_{2}\right)$ on titanium alloy for biomedical applications" Elsevier, Ceramics International, Vol.38,pp. 3435-3443,2012.

[6] Kim H, Hag Koh Y, Hao Li. L, Lee. S, Kim. H. Ee "Hydroxyapatite coating on titanium substrate with titania buffer layer processed by sol-gel method" Elsevier, Biomaterials, Vol. 25, No.2, pp.2533-2538, 2004.

[7] Škugor Rončević I., Grubač Z, Metiko .M, "Electrode position of Hydroxyapatite Coating on AZ91D Alloy for Biodegradable Implant Application", Int. J. Electrochem. Sci., Vol. 9, pp. $5907-5923,2014$.

[8] Wei .C. H, Lu .C.T, Sue .W. C, Chang .C. M "Analysis of Surface Property of $\mathrm{TiO}_{2}$ Thin Film Prepared by Sputtering, Tacking, "Journal of Science and Engineering, Vol.10, No.2, pp. 177-181, 2007.

[9] Kim. S. C, Chan Heo. M., Hong Hahn .S, "Photocatalytic Activity of Pd-Doped $\mathrm{TiO} 2$ Thin Films by Using a RF Magnetron CoSputtering Method, "Journal of the Korean 
Physical Society, Vol.47, No. 4, pp. 700-704, 2005.

[10] De Souz .M. E, Ariza .E, Ballester. M, Yoshida. I. V, Rochab L. A, Freire. C. M" Proceedings of International Corrosion "Materials Research, Vol.9, No.1, pp.59-64, 2006.

[11] Ding .S"Properties and immersion behavior of magnetron-sputtered multi-layered hydroxyapatite/titanium composite coatings" Journal of Biomaterials, Vol.24 No.3, pp.4233-4238, 2003.

[12] Fomin .A. A, Steinhauer .A. B, Rodionov. I. V, Petrova .N. V, Zakharevich.A. M. "Nanostructure of Composite Bioactive Titania Coatings Modified with Hydroxyapatite in Medical Titanium Implants, "Biomedical Engineering, Vol.47, No.3, pp.138_141, 2013.

[13] Podhorodecki, A., Zatryb G., Misiewicz. J, Domaradzki J, Kaczmarek. D"Influence of Annealing on Europium Photoexcitation
Doped into Nanocrystalline Titania Film Prepared by Magnetron Sputtering" Journal of The Electrochemical Society, Vol.156 No.3 H214-H219, pp.0013-4651,2009.

[14] Tamilselvi. S, Raman .V, Rajendran .N, Electrochimica Acta Vol.52, No.1, pp.839846, 2006.

[15] F. El-Taib Heakal, A. A. Ghoneim and A. Fekry, J. Appl. Electrochem. , vol.37, pp. 405-413, 2007.

[16] Heakal F. El, Mogoda A. S, Mazhar .A.A, ElBasiouny M. S., Corros. Sci., Vol.27, pp.4534462, 1987.

[17] Schutz .R, "An Overview of Beta Titanium Alloy Environmental Behaviour, in Beta Titanium Alloy ", The Mineral, Metals \& Materials Society, pp. 75-91.1993.

[18] Casillas .N, Charlebois S, Smyrl. W. H, White H. S, "Effects of Pores on Mechanical Properties of Plasma-Sprayed Ceramic Coatings" J. Electrochem. Soc., Vol.141, pp.636-642, 1994

\title{
ترسيب مركب من هايدروكسي ابتايت اتيتانيا على سبيكة لزراعه في جسم الانسان Ti-6Al-7Nb
}

\author{
دنيا عبد الصاحب حمدي2،2،

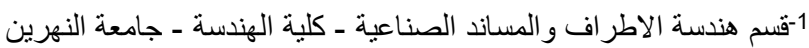

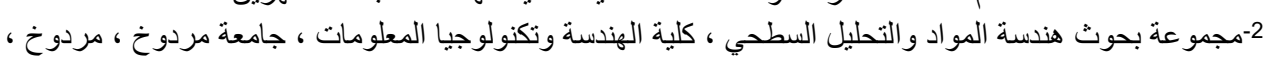 \\ WA 6150 \\ dunia_sh_7@yahoo.com
}

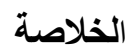

ان التحاليل التركيبيه لطبقات الطلاء وقياسات الاختبارات الكهروكيميائية بحثت في سلوك سبيكة Ti-6Al-7Nb تيتانيوم-

المنيوم -نيو بيوم المغطاة بطبقه من



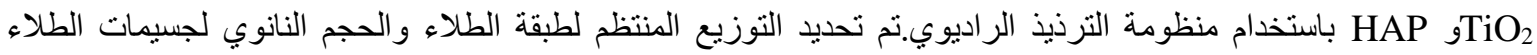
تبين عدم وجود تشققات في الطبقه المرسبه ولذلك يعود للاستخدام طبقه الطلاء

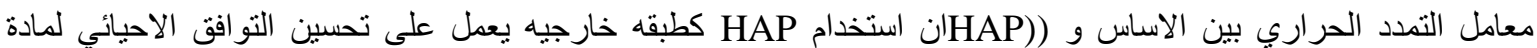
الاساس.في هذا العمل,قوة التاصر ومقاو مة التاكل تحسنت باستخدام طبقة طلاء رقيقه من .

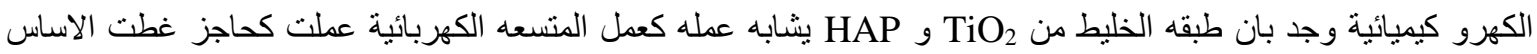
ومنعت تحرر ايونات المادة .من ملاحظة نتائج ان مقاومة طبقة الحمايه للاوكسيد اعلى من مقاومة شحنة الانتقال .مع ملاحظة الانة ان مقاومة التاكل تزداد بوجود طبقة المادة من ملاحكة الاوكسايد 